\title{
Płytki krwi - ogniwo łączące zakrzepicę ze stanem zapalnym
}

\section{Platelets - a link between hemostasis and inflammation}

\author{
Ilona Korzonek-Szlacheta ${ }^{1}$, Bartosz Hudzik ${ }^{1,2}$, Barbara Zubelewicz-Szkodzińska ${ }^{1}$, Mariusz Gąsior ${ }^{2}$ \\ ${ }^{1}$ Zakład Profilaktyki Chorób Żywieniowozależnych Wydziału Zdrowia Publicznego w Bytomiu \\ Śląskiego Uniwersytetu Medycznego w Katowicach \\ ${ }^{2}$ III Katedra i Oddział Kliniczny Kardiologii Śląskiego Centrum Chorób Serca w Zabrzu, Wydział Lekarski \\ z Oddziałem Lekarsko-Dentystycznym w Zabrzu, Śląski Uniwersytet Medyczny w Katowicach
}

\section{Streszczenie}

Główną funkcją płytek jest ich udział w procesach hemostazy. W ostatnich dwóch dekadach wzrosło znaczenie roli płytek krwi w stanach zapalnych oraz w chorobach nowotworowych. Po aktywacji płytki krwi wydzielają ponad 300 substancji z wewnątrzkomórkowych ziarnistości. Zawartość ziarnistości gęstych, między innymi: adenozynodifosforan (ADP - adenosine diphosphate), serotonina, histamina, polifosforany, i ziarnistości $\alpha$, między innymi: fibrynogen, czynnik von Willebranda, czynniki krzepnięcia, odgrywają ważną rolę w procesach hemostazy i krzepnięcia, stanowiąc również istotny czynnik powstawania przerzutów nowotworowych. Ziarnistości $\alpha$ zawierają wiele cytokin, mitogenów, czynników pro- i przeciwzapalnych oraz innych cząsteczek bioaktywnych, które są niezbędnymi regulatorami w złożonym środowisku tworzącej się skrzepliny, przyczyniając się do wielu procesów chorobowych - przede wszystkim tych związanych ze stanem zapalnym i reakcjami immunologicznymi organizmu. W niniejszej pracy poglądowej podsumowano obecne rozumienie funkcji płytek w procesach chorobowych.

Słowa kluczowe: płytki krwi, hemostaza, zapalenie, nowotwór

Folia Cardiologica 2018; 13, 4: 303-308

\section{Wstęp}

Płytki krwi są fragmentami cytoplazmy megakariocytów i zarazem najmniejszymi bezjądrowymi komórkami w organizmie. Ich liczba w ustroju osób zdrowych wynosi 140-440 G/I. Płytki krwi odgrywają podstawową rolę w zachowaniu hemostazy w organizmie, a w szczególności w hemostazie pierwotnej, zanim uruchomione zostaną szlaki kaskady krzepnięcia. Zaburzenia liczby i funkcji płytek krwi prowadzą do krwawień [1].

Udział płytek krwi w procesie hemostazy można podzielić na kilka etapów częściowo zachodzących na siebie [1, 2]: - adhezje - przyleganie do miejsca uszkodzonego śródbłonka poprzez wiązanie kompleksu receptorów Ib/V/IX na płytkach krwi z odsłoniętymi włóknami kolagenu. Ten etap hemostazy pierwotnej wzmagany jest przez czynniki von Willebranda (vWF, von Willebrand factor), który wiążąc się z glikoproteiną lb (GP Ib) zwiększa siłę związania płytek krwi z kolagenem;

- aktywacje - wiązanie płytek krwi z uszkodzonymi tkankami prowadzi do aktywacji płytek krwi poprzez liczne substancje, między innymi: ADP, tromboksan A2, kolagen, czy trombine. Najsilniejszym agonistą jest trombina. Aktywacja płytek krwi prowadzi do zmiany ich kształtu i intensywniejszego uwalniania różnych związków w ziarnistości płytek krwi. Wspólnym końcowym ogniwem aktywacji płytek krwi jest receptor błonowy GP Ilb/IIla, który zwiększa adhezję i agregację płytek krwi;

Adres do korespondencji: dr n. med. Ilona Korzonek-Szlacheta, Zakład Profilaktyki Chorób Żywieniowozależnych, Wydział Zdrowia Publicznego w Katowicach, ul. Piekarska 18, 41-900 Bytom, tel. 3239765 32, e-mail: bartekh@mp.pl 
- wydzielanie - płytki krwi zawierają ziarnistości, w których są magazynowane różne związki (tab. 1):

- ziarnistości $\alpha$ - zawierają białka swoiste dla płytek krwi, między innymi: płytkowy czynnik wzrostu (PDGF, platelet-derived growth factor), transformujący czynnik wzrostu $\beta$ (TGF- $\beta$, transforming growth factor $\beta$ ), chemokiny, cytokiny (interleukina $1 \beta$ ), cząsteczki adhezyjne, biała układu krzepnięcia (czynnik V, białko S, czynnik XI, czynnik XIII), czynnik płytkowy 4, vWF itp.,

- ziarnistości (ciałka) gęste $\delta$ - zawierają ADP, adenozynotrifosforan (ADP, adenosine triphosphate), guanozynodifosforan (GDP, guanosine diphosphate), guanozynotrifosforan (GDP, guanosine triphosphate), dwuwartościowe kationy $\left(\mathrm{Ca}^{2+}, \mathrm{Mg}^{2+}\right)$, serotoninę i histaminę.

Degranulacja jest procesem zależnym od jonów wapnia i prowadzi do reorganizacji cytoszkieletu płytek krwi i amplifikacji procesu aktywacji;

- agregacja - wymaga licznych interakcji płytka krwi płytka krwi i prowadzi do powstania hemostatycznego czopu płytkowego. Najważniejszym elementem tego etapu jest receptor płytkowy GP IIb/IIla dla fibrynogenu. Zdolność wiązania fibrynogenu płytka uzyskuje jednak dopiero po zmianach konformacji GP Ilb/IIla wywoływanych przez wielu agonistów.

Nadmierna aktywacja płytek krwi, prowadząca do zakrzepicy w świetle naczyń, występuje na podłożu miażdżycy w przebiegu ostrych zespołów wieńcowych oraz mózgowych incydentów niedokrwiennych i jest jednym z głównych czynników wpływających na chorobowość i śmiertelność. Wprowadzenie leków przeciwpłytkowych istotnie poprawiło rokowanie w tych schorzeniach. Obecnie trwają badania nad nowymi molekułami ingerującymi zarówno w dotychczas poznane, jak i nowe szlaki prowadzące do aktywacji i agregacji płytek krwi.
Tabela 1. Substancje syntetyzowane w płytkach krwi i magazynowane w ziarnistości lub w cytoplazmie

\begin{tabular}{|c|c|}
\hline \multirow[t]{7}{*}{ Ziarnistości $\alpha$} & $\begin{array}{l}\text { Glikoproteiny adhezyjne: P-selektyna, } \\
\text { vWF, fibrynogen, trombospondyna }\end{array}$ \\
\hline & $\begin{array}{l}\text { Czynniki krzepnięcia: czynnik V, białko S, } \\
\text { czynnik XI, czynnik XIII }\end{array}$ \\
\hline & Czynniki mitogenne: PDGF, TGF- $\beta$, EGF \\
\hline & Czynniki angiogenne: VEGF, inhibitor PF4 \\
\hline & Inhibitory fibrynolizy: PAI-I \\
\hline & $\begin{array}{l}\text { Chemokiny: CXCL7, CXCL4, CHCL1, } \\
\text { CXCL5, CCL5 (RANTES), CCL3 }\end{array}$ \\
\hline & Cytokiny: IL-1 $\beta$, TGF- $\beta$ \\
\hline \multirow[t]{3}{*}{ Ziarnistości $\delta$} & Aminy: histamina, serotonina \\
\hline & Kationy dwuwartościowe: $\mathrm{Ca}^{2+}, \mathrm{Mg}^{2+}$ \\
\hline & Nukleotydy: ATP, ADP, GTP, GDP \\
\hline \multirow[t]{2}{*}{$\begin{array}{l}\text { Ziarnistości } \\
\text { lizosomalne }\end{array}$} & $\begin{array}{l}\text { Kwaśne proteazy: karboksypeptydazy, } \\
\text { katepsyny, kwaśna fosfataza, kolagenaza }\end{array}$ \\
\hline & Glikohydrolazy \\
\hline $\begin{array}{l}\text { Inne rozpuszczal- } \\
\text { ne mediatory }\end{array}$ & $\begin{array}{l}\text { CCL7, IL-1 } \beta \text {, defenzyny, tromboksan A2, } \\
\text { PAF, sCD40L }\end{array}$ \\
\hline
\end{tabular}

\section{Płytki krwi a układ immunologiczny i stan zapalny}

Funkcja płytek krwi w utrzymaniu hemostazy została dokładnie zbadana, lecz coraz częściej nowe dowody naukowe wskazują także na centralną rolę płytek krwi w reakcjach zapalnych i odpowiedzi immunologicznej (tab. 1, 2, ryc. 1). Płytki krwi, ze względu na ich dużą liczbę oraz zdolność do szybkiego uwalniania szerokiego spektrum cytokin, chemokin i innych mediatorów o właściwościach

Tabela 2. Substancje uwalniane z płytek krwi biorące udział w odpowiedzi immunologicznej

\begin{tabular}{|c|c|c|}
\hline Czynniki wzrostu & PDGF & Różnicowanie monocytów i makrofagów \\
\hline Cytokiny & IL-1 $\beta$, TGF- $\beta$ & $\begin{array}{l}\text { Różnicowanie limfocytów T, limfocytów B i makrofagów, proliferacja komórkowa, } \\
\text { chemotaksja, uwalnianie chemokin i cytokin, zwiększenie ekspresji cząsteczek adhe- } \\
\text { zyjnych na leukocytach }\end{array}$ \\
\hline \multirow[t]{2}{*}{ Chemokiny } & CCL5, CXCL12 & Chemotaksja monocytów, neutrofili i limfocytów T \\
\hline & Trombomodulina (CXCL1) & Rekrutacja i aktywacja neutrofili, aktywacja fagocytozy makrofagów \\
\hline \multirow[t]{5}{*}{ Inne związki } & Metaloproteinazy & Tworzenie agregatów leukocytarno-płytkowych \\
\hline & P-selektyna & Adhezja leukocytów i aktywację składników dopełniacza \\
\hline & Trombospondyna & Apoptoza, proces zapalny komórek śródbłonka, agregacja płytkowo-makrofagowa \\
\hline & Histamina & Aktywacja monocytów i limfocytów T \\
\hline & P-selektyna & Adhezja leukocytów do płytek krwi i komórek śródbłonka \\
\hline
\end{tabular}




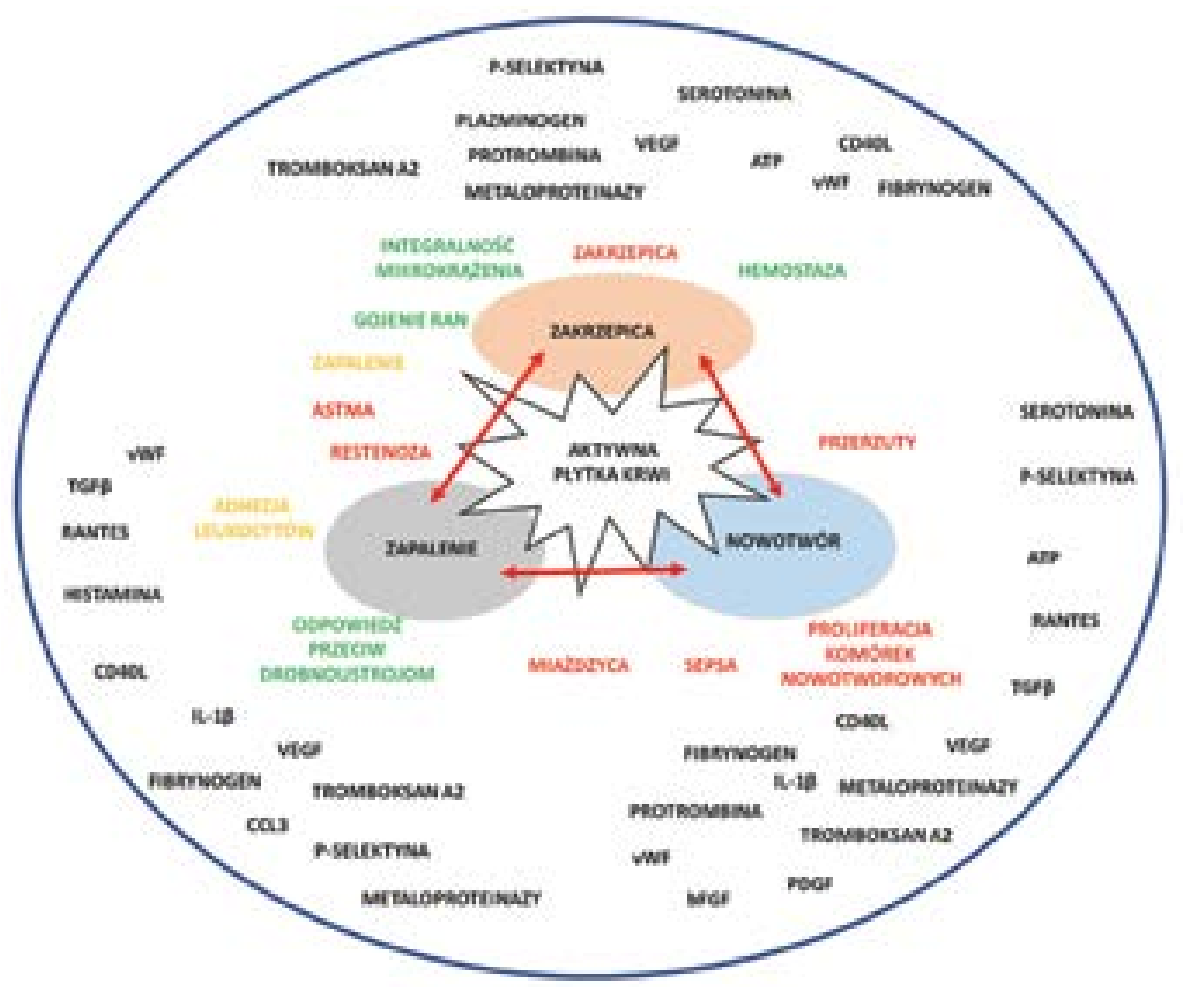

Rycina 1. Wielokierunkowa funkcja płytek krwi i jej mediatory stanowiące podstawę procesów fizjologicznych (kolor zielony), patologicznych (kolor czerwony) lub obu jednocześnie (kolor żółty)

immunomodulujących, spełniają funkcję krążących strażników [2-5].

Na powierzchni płytek krwi znajdują się liczne receptory rozpoznające wzorce, inaczej receptory rozpoznające patogeny (PRR, pattern recognition receptors, pathogen recognition receptors) odgrywające ważną rolę w mechanizmach odporności immunologicznej nieswoistej organizmu. Dzięki receptorom rozpoznającym wzorce (PRR) organizm jest w stanie odróżnić cząsteczki wchodzące w skład własnych tkanek od antygenów drobnoustrojów [2, 6, 7].

Jednym z przedstawicieli PRR są receptory TLR (Toll-podobne), które odgrywają główną rolę w rozpoznaniu zagrożenia i inicjacji odpowiedzi immunologicznej. Wśród komórek rozpoznających patogeny za pomocą receptorów TLR wyróżnia się: komórki układu immunologicznego (makrofagi, komórki dendrytyczne, komórki tuczne, eozynofile, neutrofile, limfocyty B), komórki nabłonkowe, komórki śródbłonka, płytki krwi, kardiomiocyty i adipocyty [7].

Ziarnistości $\alpha$ stanowią najliczniejsze ziarnistości w płytkach krwi. Ich zawartość ulega szybkiej egzocytozie podczas aktywacji płytek krwi, a uwalniane mediatory wzmagaja procesy hemostazy i stanu zapalnego. Ponadto niektóre mediatory uwalniane z tych ziarnistości (np. selektyna P, fibrynogen, vWF, trombospondyna, fibronektyna) ułatwiają interakcje między płytkami krwi, leukocytami, białkami osocza oraz ściana naczyń. Mediatory uwalniane z ziarnistości $\delta$ nasilają agregację, wazokonstrykcję oraz syntezę cytokin prozapalnych $[3,5,6]$. Biorąc pod uwagę ogromną liczbę krążących płytek krwi oraz liczne receptory immunologiczne, magazynowanie immunomodulacyjnych mediatorów i cząsteczek adhezyjnych, płytki krwi mają duży potencjał inicjacji oraz kształtowania reakcji zapalnej w trakcie odpowiedzi immunologicznej. Doniesienia wskazują, że u pacjentów z ciężkimi zakażeniami bakteryjnymi lub wirusowymi dochodzi do małopłytkowości, co wskazuje, że płytki krwi są aktywnie rekrutowane do udziału w odpowiedzi zapalnej. Co więcej, badania eksperymentalne wskazuja, że płytki krwi biora mogą aktywnie wiązać krążące bakterie i prezentować je neutrofilom oraz komórkom układu siateczkowo-śródbłonkowego. W tym procesie interakcja płytek z neutrofilami może dodatkowo prowadzić do tworzenia zewnątrzkomórkowych chromatynowych fibryli zawierających jądrowe DNA (NET, neutrophil extracellular traps), które usprawniają usuwanie („chwytanie”) drobnoustrojów z organizmu [6, 8].

Jednak udział płytek krwi w procesach zapalnych oraz odpowiedzi immunologicznej ma także złe strony. Liczne badania sugerują, że agregaty płytek krwi i leukocytów, często związane z posocznicą, w obrębie mikrokrążenia prowadzą do niedokrwienia, a to z kolei może spowodować wyraźne uszkodzenie tkanki i dysfunkcję narządu. Co więcej, rośnie liczba dowodów na to, że nadmierna produkcja NET i osadzanie związanych z nimi cytotoksycznych cząsteczek na śródbłonku może prowadzić do śmierci komórkowej i uszkodzenia tkanek [6]. 
Aktywacja płytek krwi jest ogniwem, które w patofizjologii łączy zakrzepicę i stan zapalny. Przebadano liczne markery płytek krwi, między innymi średnią objętość płytki krwi (MPV, mean platelet volume), w związku z zakrzepicą i zapaleniem [9]. Uznane czynniki ryzyka sercowo-naczyniowego, takie jak palenie tytoniu, nadciśnienie tętnicze, hiperlipidemia i cukrzyca, mogą wpływać na MPV. Niski stopień zapalenia (LGI, low grade inflammation) jest także jednym z takich czynników. Dowody naukowe, w szczególności pochodzące z badań prospektywnych i metaanaliz, sugerują korelację między zwiększoną MPV a ryzykiem zakrzepicy i podwyższonym ryzykiem sercowo-naczyniowym [9]. W reakcjach zapalnych w obrębie ściany tętnicy wieńcowej pośredniczą przez liczne czynniki, w tym, ale nie wyłącznie, białko C-reaktywne (CRP, C-reactive protein), cytokiny, chemokiny, czynniki wzrostu i cząsteczki adhezyjne [10]. Białko C-reaktywne należy do rodziny krótkich pentraksyn (PTX, pentraxin). W ostatnich dwóch dekadach zainteresowanie badaczy skupiło się na pentraksynie 3 (PTX-3, pentraxin 3), która należy do rodziny długich pentraksyn. Jest ona produkowana w miejscu uszkodzenia ściany naczynia (miejscowy proces zapalny) w odróżnieniu do CRP, które jest syntetyzowane w wątrobie [11]. Pentraksynę 3 produkują monocyty/makrofagi, komórki śródbłonka, komórki mięśni gładkich ściany naczyń, fibroblasty i adipocyty [12]. Istnieją doniesienia wskazujące na zwiększone wskaźniki objętościowe płytek krwi (MPV, wskaźnik anizocytozy płytek krwi [PDW, platelet distribution width]) u pacjentów z podwyższonym stężeniem PTX-3 [13].

\section{Płytki krwi a procesy gojenia}

Funkcja płytek krwi w procesie hemostazy ma na celu zahamowania krwawienia z uszkodzonej ściany naczynia wywołanej urazem. Ostatnim etapem odpowiedzi hemostatycznej na zewnętrzny uraz lub pęknięcie blaszki miażdżycowej jest przywrócenie integralności ściany naczyń krwionośnych. Na ten proces składa się proliferacja i migracja komórek mięśni gładkich, fibroblastów oraz komórek śródbłonka [14]. Czynniki wzrostu uwalniane z płytek krwi (PDGF, czynnik wzrostu śródbłonka naczyniowego [VEGF, vascular endothelial growth factor]) oraz niektóre cytokiny i chemokiny regulują te procesy [14]. W badaniach eksperymentalnych przeprowadzonych w ostatnim ćwierćwieczu wykazano związek czynników wzrostowych (PDGF, VEGF) z hiperplazją neointimy i restenozą [15-18]. Jednak modulacja sekrecji czynników związanych z procesami gojenia dla uzyskania korzyści klinicznych pozostaje nadal obszarem wymagającym dalszych badań.

\section{Płytki krwi a nowotwory}

Płytki krwi odgrywają istotną rolę w patogenezie chorób nowotworowych. Istnieją obecnie dowody na udział płytek krwi w proliferacji komórek nowotworowych, powstawaniu przerzutów i angiogenezie [19-21]. Zjawiska te zostały potwierdzone na modelach zwierzęcych dla różnych nowotworów, w tym raka piersi, okrężnicy, płuc, jajnika i czerniaka. Interakcje płytek krwi i komórek nowotworowych są dwukierunkowe [21]. Zarówno białka na powierzchni komórek nowotworowych aktywują płytki krwi, jak i aktywne płytki promują przeżycie komórek nowotworowych i ich rozprzestrzenianie. Procesy te zachodzą poprzez szereg różnych mechanizmów. Tworzenie agregatów złożonych z komórek nowotworowych i płytek krwi zwiększa przeżycie komórek nowotworowych poprzez ich ochronę przed nadzorem immunologicznym. Pozwala to na ich przetrwanie w układzie krążenia i zwiększa potencjał przerzutowy. Płytki krwi ułatwiają adhezję komórek nowotworowych do ściany naczynia, a uwalniając czynniki wzrostu przyczyniają się wzrostu komórek nowotworowych i angiogenezy w obrębie guza [19-21]. Mechanizmy przez które płytki krwi przyczyniają się do przerzutów obejmują: 1) zatrzymanie komórek nowotworowych w miejscach uszkodzenia naczyń przy udziale P-selektyny występującej na powierzchni płytek krwi lub komórek śródbłonka, a następnie stabilna adhezja za pośrednictwem integryny; 2) stworzenie fizycznej bariery chroniącej komórki nowotworowe przed usunięciem przez komórki odpowiedzi immunologicznej (np. komórki naturalnej cytotoksyczności [NK, natural killers]) [22, 23]. Badania kliniczne wykazały, że zwiększona liczba płytek krwi jest związana z chorobą nowotworową w większym stopniu zaawansowania, a także jest niekorzystnym marker prognostycznym [24-27]. Ponadto, od niedawna bada się także wskaźniki, które łączą wartość prognostyczną parametrów płytkowych z wartością prognostyczną parametrów stanu zapalnego. Do tych wskaźników należy między innymi stosunek liczby płytek krwi do limfocytów (PLR, platelet-to-lymphocyte ratio). Po raz pierwszy PLR wprowadzono jako potencjalny marker do określania nasilenia stanu zapalnego u pacjentów z chorobami onkologicznymi $[28,29]$. Co ciekawe, PLR okazał się istotnym markerem zapalnym pod względem rokowniczym w populacji pacjentów z chorobą nowotworową [30-32].

\section{Podsumowanie}

Hemostaza stanowi przeważającą część funkcji płytek krwi, w której odgrywają one złożoną rolę zintegrowaną z innymi rozpuszczalnymi i komórkowymi składnikami krwi. Jednak jest teraz jasne, że płytki krwi mają szerszy repertuar ról fizjologicznych i dlatego są zaangażowane w większą liczbę stanów patologicznych niż tylko zakrzepica.

\section{Konflikt interesów}

Autorzy nie zgłaszają żadnego konfliktu interesów dotyczącego niniejszej pracy. 


\section{Abstract}

The main function of platelets is participation in hemostasis. During the last two decades, our understanding of the role of platelets in inflammation and neoplastic diseases has considerably increased. After activation, platelets secrete over 300 substances from intracellular granules. The molecules contained in platelet dense granules, including ADP, serotonin, histamine and polyphosphates, and $\alpha$ granules, including fibrinogen, von Willebrand factor, and coagulation factors, play an important role in hemostasis and coagulation processes, but also are factors involved in the development of cancer metastases. Alpha granules contain many cytokines, mitogens, pro- and anti-inflammatory factors and other bioactive molecules, which are necessary regulators in the complex environment of thrombus formation, but are also involved in many pathological processes - primarily those associated with inflammation and immune responses. In this review, we summarize the current knowledge of platelet function in pathological processes.

Key words: platelets, hemostasis, inflammation, cancer

Folia Cardiologica 2018; 13, 4: 303-308

\section{Piśmiennictwo}

1. Clemetson KJ, Lu Q, Navdaev A, et al. Primary haemostasis: sticky fingers cement the relationship. Curr Biol. 1999; 9(3): R110-R112, indexed in Pubmed: 10021379.

2. Jenne CN, Urrutia R, Kubes P. Platelets: bridging hemostasis, inflammation, and immunity. Int J Lab Hematol. 2013; 35(3): 254-261, doi: 10.1111/ijlh.12084, indexed in Pubmed: 23590652.

3. Ware J, Corken A, Khetpal R. Platelet function beyond hemostasis and thrombosis. Curr Opin Hematol. 2013; 20(5): 451-456, doi: 10.1097/ /MOH.Ob013e32836344d3, indexed in Pubmed: 23839296.

4. Thachil J. Platelets in Inflammatory Disorders: A Pathophysiological and Clinical Perspective. Semin Thromb Hemost. 2015; 41(6): 572-581, doi: 10.1055/s-0035-1556589, indexed in Pubmed: 26276938.

5. Weyrich AS, Lindemann S, Zimmerman GA. The evolving role of platelets in inflammation. J Thromb Haemost. 2003; 1(9): 1897-1905, indexed in Pubmed: 12941029.

6. McFadyen JD, Kaplan ZS. Platelets are not just for clots. Transfus Med Rev. 2015; 29(2): 110-119, doi: 10.1016/j.tmrv.2014.11.006, indexed in Pubmed: 25680870.

7. Dolasia K, Bisht MK, Pradhan G, et al. TLRs/NLRs: Shaping the landscape of host immunity. Int Rev Immunol. 2018; 37(1): 3-19, doi: 10.1080/08830185.2017.1397656, indexed in Pubmed: 29193992.

8. Clark SR, Ma AC, Tavener SA, et al. Platelet TLR4 activates neutrophil extracellular traps to ensnare bacteria in septic blood. Nat Med. 2007; 13(4): 463-469, doi: 10.1038/nm1565, indexed in Pubmed: 17384648.

9. Gasparyan AY, Ayvazyan L, Mikhailidis DP, et al. Mean platelet volume: a link between thrombosis and inflammation? Curr Pharm Des. 2011; 17(1): 47-58, indexed in Pubmed: 21247392.

10. Libby P, Ridker PM. Inflammation and atherosclerosis: role of C-reactive protein in risk assessment. Am J Med. 2004; 116 Suppl 6A: 9S-916S, doi: 10.1016/j.amjmed.2004.02.006, indexed in Pubmed: 15050187.

11. Nakou ES, Liberopoulos EN, Milionis HJ, et al. The role of C-reactive protein in atherosclerotic cardiovascular disease: an overview. Curr Vasc Pharmacol. 2008; 6(4): 258-270, indexed in Pubmed: 18855714.

12. Abderrahim-Ferkoune $A$, Bezy 0 , Chiellini $C$, et al. Characterization of the long pentraxin PTX3 as a TNFalpha-induced secreted protein of adipose cells. J Lipid Res. 2003; 44(5): 994-1000, doi: 10.1194/jlr. M200382-JLR200, indexed in Pubmed: 12611905.
13. Korzonek-Szlacheta I, Danikiewicz A, Szkodziński J, et al. Relationship Between Plasma Pentraxin 3 Concentration and Platelet Indices in Patients With Stable Coronary Artery Disease. Angiology. 2018; 69(3): 264-269, doi: 10.1177/0003319717732929, indexed in Pubmed: 28946774.

14. Nurden AT. The biology of the platelet with special reference to inflammation, wound healing and immunity. Front Biosci (Landmark Ed). 2018; 23: 726-751, indexed in Pubmed: 28930569.

15. McNamara CA, Sarembock IJ, Bachhuber BG, et al. Thrombin and vascular smooth muscle cell proliferation: implications for atherosclerosis and restenosis. Semin Thromb Hemost. 1996; 22(2): 139-144, doi: 10.1055/s-2007-999001, indexed in Pubmed: 8807710.

16. Folestad E, Kunath A, Wågsäter D. PDGF-C and PDGF-D signaling in vascular diseases and animal models. Mol Aspects Med. 2018; 62: 1-11, doi: 10.1016/j.mam.2018.01.005, indexed in Pubmed: 29410092.

17. Andrae J, Gallini R, Betsholtz C. Role of platelet-derived growth factors in physiology and medicine. Genes Dev. 2008; 22(10): 1276-1312, doi: 10.1101/gad.1653708, indexed in Pubmed: 18483217.

18. Kowalczyk J, Pasyk S. [Vascular endothelial growth factor and its application in therapy of cardiovascular diseases]. Pol Merkur Lekarski. 2002; 13(73): 74-78, indexed in Pubmed: 12362514.

19. Mezouar S, Frère C, Darbousset R, et al. Role of platelets in cancer and cancer-associated thrombosis: Experimental and clinical evidences. Thromb Res. 2016; 139: 65-76, doi: 10.1016/j. thromres.2016.01.006, indexed in Pubmed: 26916298.

20. Zhang Q, Liu H, Zhu Q, et al. Patterns and functional implications of platelets upon tumor „education”. Int J Biochem Cell Biol. 2017; 90: 68-80, doi: 10.1016/j.biocel.2017.07.018, indexed in Pubmed: 28754316.

21. Stegner D, Dütting S, Nieswandt B. Mechanistic explanation for platelet contribution to cancer metastasis. Thromb Res. 2014; 133 Suppl 2: S149-S157, doi: 10.1016/S0049-3848(14)50025-4, indexed in Pubmed: 24862136.

22. Li N. Platelets in cancer metastasis: To help the „villain” to do evil. Int J Cancer. 2016; 138(9): 2078-2087, doi: 10.1002/ijc.29847, indexed in Pubmed: 26356352.

23. Li Y, Miao LY, Xiao YL, et al. Elevated platelets enhance cancer cell migration, promote hematogenous metastasis and associate with 
a poor prognosis in advanced non-small cell lung cancer cases. Asian Pac J Cancer Prev. 2014; 15(1): 139-143, indexed in Pubmed: 24528015.

24. Tranum BL, Haut A. Thrombocytosis: platelet kinetics in neoplasia. J Lab Clin Med. 1974; 84(5): 615-619, indexed in Pubmed: 4283783.

25. Hernandez E, Lavine M, Dunton CJ, et al. Poor prognosis associated with thrombocytosis in patients with cervical cancer. Cancer. 1992; 69(12): 2975-2977, indexed in Pubmed: 1591690.

26. Zeimet AG, Marth C, Müller-Holzner E, et al. Significance of thrombocytosis in patients with epithelial ovarian cancer. Am J Obstet Gynecol. 1994; 170(2): 549-554, indexed in Pubmed: 8116711.

27. Ikeda M, Furukawa $\mathrm{H}$, Imamura $\mathrm{H}$, et al. Poor prognosis associated with thrombocytosis in patients with gastric cancer. Ann Surg Oncol. 2002; 9(3): 287-291, indexed in Pubmed: 11923136.

28. Kwon HC, Kim SH, Oh SY, et al. Clinical significance of preoperative neutrophil-lymphocyte versus platelet-lymphocyte ratio in patients with operable colorectal cancer. Biomarkers. 2012; 17(3): 216-222, doi: 10.3109/1354750X.2012.656705, indexed in Pubmed: 22424597.
29. Feng JF, Huang Y, Zhao Q, et al. Clinical significance of preoperative neutrophil lymphocyte ratio versus platelet lymphocyte ratio in patients with small cell carcinoma of the esophagus. ScientificWorldJournal. 2013; 2013: 504365, doi: 10.1155/2013/504365, indexed in Pubmed: 24089602.

30. Proctor MJ, Morrison DS, Talwar D, et al. A comparison of inflammation-based prognostic scores in patients with cancer. A Glasgow Inflammation Outcome Study. Eur J Cancer. 2011; 47(17): 2633-2641, doi: 10.1016/j.ejca.2011.03.028, indexed in Pubmed: 21724383.

31. Smith RA, Ghaneh P, Sutton R, et al. Prognosis of resected ampullary adenocarcinoma by preoperative serum CA19-9 levels and platelet-lymphocyte ratio. J Gastrointest Surg. 2008; 12(8): 1422-1428, doi: 10.1007/s11605-008-0554-3, indexed in Pubmed: 18543046.

32. Smith RA, Bosonnet L, Raraty M, et al. Preoperative platelet-lymphocyte ratio is an independent significant prognostic marker in resected pancreatic ductal adenocarcinoma. Am J Surg. 2009; 197(4): 466-472, doi: 10.1016/j.amjsurg.2007.12.057, indexed in Pubmed: 18639229. 